\title{
Article \\ Effects of Defoliation at Fruit Set on Vine Physiology and Berry Composition in Cabernet Sauvignon Grapevines
}

\author{
Eleonora Cataldo (D), Linda Salvi (D), Francesca Paoli, Maddalena Fucile and Giovan Battista Mattii *(D) \\ Department of Agriculture, Food, Environment and Forestry (DAGRI), University of Florence, \\ 50019 Sesto Fiorentino, Italy; eleonora.cataldo@unifi.it (E.C.); linda.salvi@unifi.it (L.S.); \\ francesca.paoli@unifi.it (F.P.); maddalena.fucile@unifi.it (M.F.) \\ * Correspondence: giovanbattista.mattii@unifi.it; Tel.: +39-05-5457-4043
}

check for updates

Citation: Cataldo, E.; Salvi, L.; Paoli, F.; Fucile, M.; Mattii, G.B. Effects of Defoliation at Fruit Set on Vine Physiology and Berry Composition in Cabernet Sauvignon Grapevines. Plants 2021, 10, 1183. https:// doi.org/10.3390/plants10061183

Academic Editor: Rebecca Grumet

Received: 20 May 2021

Accepted: 8 June 2021

Published: 10 June 2021

Publisher's Note: MDPI stays neutral with regard to jurisdictional claims in published maps and institutional affiliations.

Copyright: (c) 2021 by the authors. Licensee MDPI, Basel, Switzerland. This article is an open access article distributed under the terms and conditions of the Creative Commons Attribution (CC BY) license (https:// creativecommons.org/licenses/by/ $4.0 /)$.

\begin{abstract}
Grapevine canopy defoliation is a fundamentally important technique for the productivity and quality of grapes. Leaf removal is a pivotal operation on high-density vines which aims to improve air circulation, light exposure, and leaf gas exchange. The effects of leaf removal (LR) on vine physiology and berry composition in Cabernet Sauvignon grapevines were studied during the 2018-2019 growing season in the Bolgheri area, Tuscany, Italy. The basal leaves were removed at fruit set at two severity levels (removal of four basal leaves of each shoot (LR4) and removal of eight basal leaves (LR8)). The two treatments were compared with the not defoliated control (CTRL). The following physiological parameters of vines were measured: leaf gas exchange, leaf water potential, chlorophyll fluorescence and indirect chlorophyll content. The results showed that defoliation increased single leaf photosynthesis. In addition, qualitative grape parameters (phenolic and technological analyses) and daytime and night-time berry temperature were studied. The results showed that leaf removal had an impact on total soluble solids ( ${ }^{\circ}$ Brix), titratable acidity, and $\mathrm{pH}$. The LR8-treated grapes had higher titratable acidity, while those in the LR4 treatment had higher ${ }^{\circ}$ Brix and extractable anthocyanin and polyphenol content. Berry weight was not significantly influenced by the timing and severity of basal defoliation. Therefore, this research aims to investigate the effects of defoliation at the fruit set on vines performance.
\end{abstract}

Keywords: leaf removal; defoliation; berry temperature; sugar content; anthocyanin content

\section{Introduction}

Defoliation in the fruiting zone of grapevines is a classical canopy management practice in vineyards applied from spring until the end of summer [1]. Improvement of the microclimate after defoliation is mainly attributed to the increase in bunch temperature and modification of the shadow-light ratio [2-4]. Furthermore, this practice improves berry quality (for instance, pigmentation, aromatic compounds, and secondary metabolites), whereas it reduces conditions favorable to bunch rot complex diseases [5-7]. Even though leaf removal is more often applied to vigorous vines or in chilly climates where the environmental conditions and cluster microclimate are often inadequate to ensure adequate berry ripening [8], this agronomic practice is widely used, even in warmer climates and on plants that are not excessively vigorous to improve their performance. However, defoliation must be undertaken with care to prevent the risk of berry overheating and burning [9]. To obtain a high-quality grape and wine, many authors highlight the importance of achieving and maintaining the optimal ratio between grape yield and assimilation area [10-12]. In fact, quality viticulture is correlated to a balance between plant and agronomic management [13] and must address the match between reproductive organs and vegetative sink activity.

The effect of defoliation depends on the number of removed leaves, timing, grape variety, and climate [14]. Depending on the phenological stage, defoliation can be performed early (at pre-flowering), medium (at fruit set) or late (pre- or post-veraison). Early defoliation decreases grape yield by decreasing berry number and thus, cluster weight, 
whereas leaf removal during or after veraison impacts the primary and secondary synthesis of metabolites [15]. Nevertheless, some studies have shown that early leaf thinning can improve grape and wine quality. Defoliation before flowering was found to decrease fruit set and reduce grape yield of many varieties (e.g., Sangiovese, Merlot, Tempranillo), whereas under different microclimatic conditions, it increased anthocyanin and phenolic concentrations [6,16-20]. Moreover, the effects of leaf removal on yield also depend on severity [21-23]. Since carbohydrate supply at anthesis is a fundamental determinant of fruit set, leaf removal three or four weeks before anthesis normally reduces cluster compactness, yield, and total amount of sugar per berry [24]. On the other hand, if leaves are removed later in the phenological season (e.g., veraison) or fewer are removed (lower severity), yield is not significantly affected and it can even increase compared with nondefoliated treatments [25]. However, pre-flowering defoliation presents some risks as removing most of the photosynthetically active foliage when inflorescences have high $C$ and $\mathrm{N}$ requirements forces the vine to further rely on reserves in roots and wood (competition for assimilates between reproductive and vegetative organs) [26,27]. Percival et al. [28] noted that with pre-flowering defoliation and the consequent increased exposure to solar radiation, a thicker layer of cuticular waxes was formed and correlated this thickening with increased resistance to cluster rot [29].

Fruit set defoliation is an efficient technique to reduce cluster compactness, to improve fruit composition, and control crop load in cultivars characterized by large berry size and improve their health [30].

Defoliation after flowering and at fruit set (compared with leaf removal at veraison) of all basal leaves up to the first cluster increases not only monoterpen content (especially nerol, linalool, and geraniol) but also alcohol, and decreases the concentration of volatile esters in white berries [31-34]. Conversely, shading in the canopy has implications for red berry alterations: an excessively shaded canopy microclimate can cause increased titratable acidity (malic and tartaric acids) and juice $\mathrm{NH}_{4}-\mathrm{N}$ and $\mathrm{K}$ content [35]. Changes in berry composition due to shade can be associated with known effects of the phytochrome on enzyme activity (including malic enzyme, phenylalanine ammonia lyase, invertase, PEP-carboxylase, and malic dehydrogenase) $[4,36,37]$.

Many authors have reported balancing berry physiology ripening between technological and phenolic maturation, decreasing the accumulation of sugar, and manipulating the relationship between leaf area and yield by intervening at different phenological stages [38-41]. Among these, post-veraison defoliation seems to be the most promising. Poni [42] and Filippetti [43] reported that late defoliation, removing six or seven basal leaves and some lateral shoots from the upper two-thirds of the canopy, in Sangiovese cultivar caused sugar accumulation (at about $12{ }^{\circ}$ Brix) to decrease without negatively affecting the concentration of anthocyanin and phenolic compounds. Nevertheless, leaf thinning can also affect cluster quality negatively. In fact, an excessive defoliation can lead to overexposed fruit (subjecting the berries to high temperature and high light intensity) and, in red cultivars, can reduce anthocyanin content [44].

The present investigation examines the effects of defoliation at fruit set on cv. Cabernet Sauvignon in local Mediterranean conditions with attention to the alternative severity of defoliation, especially to its effects on ecophysiological parameters, yield reduction, sugar and anthocyanin content.

\section{Results}

\subsection{Climatic Conditions}

Temperature conditions were those typical of warm-Mediterranean viticulture climates, as reported in Figure 1.

Rainfall throughout the season, April to October, was relatively higher in 2019 with $378.4 \mathrm{~mm}$ recorded, while during the berry ripening period (from June to August), 2019 turned out to be drier: $29.4 \mathrm{~mm}$ compared to $39.8 \mathrm{~mm}$ in 2018. The average air temperature, from April to October, was $20.2{ }^{\circ} \mathrm{C}$ in 2018 and $20.8^{\circ} \mathrm{C}$ in 2019 . The absolute maximum air 
temperature during the investigated period ranged from $33.4{ }^{\circ} \mathrm{C}$ in August 2018 to $35.4{ }^{\circ} \mathrm{C}$ in August 2019.
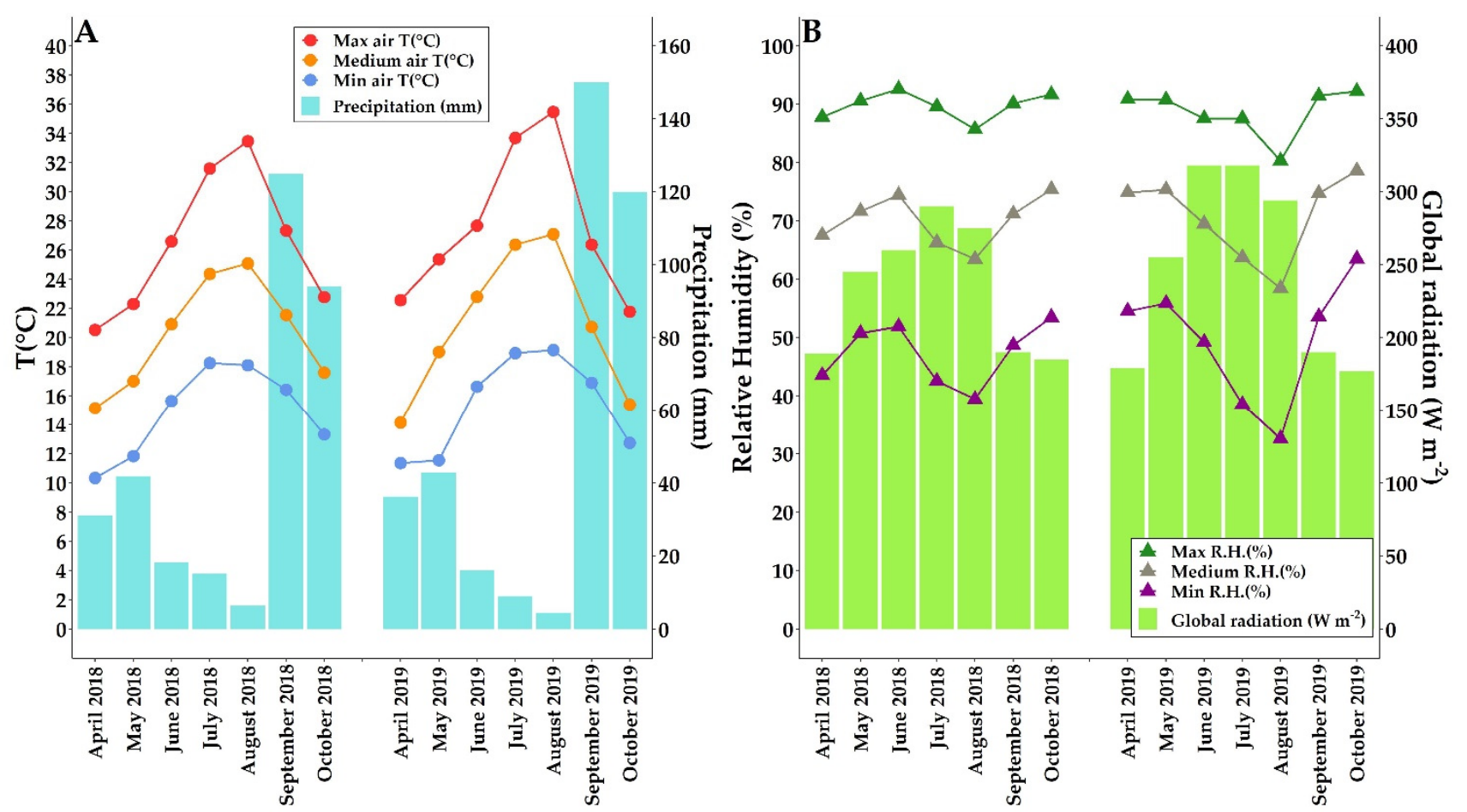

Figure 1. Climatic conditions of the experiment location. Monthly averages of mean, maximum, minimum air temperature $\left({ }^{\circ} \mathrm{C}\right)$ and total monthly rainfall (mm) (A) were measured from April to October (2018-2019); monthly averages of mean, maximum, minimum relative humidity $(\%)$, and average monthly global radiation (RAD, $\left.\mathrm{W} \mathrm{m}^{-2}\right)(\mathbf{B})$ were measured from April to October (2018-2019).

\subsection{Leaf Gas Exchanges, Leaf Area, Leaf Water Potential, Leaf Chlorophyll a Fluorescence and Content}

The total leaf area $\left(\mathrm{m}^{2}\right)$ is presented in Table 1 . The highest leaf area was observed in the control and the lowest in the LR8 treatment. All differences among the values were significant. The first measurement concerned the relief immediately after defoliation at the time of fruit set (18 June 2018 and 12 June 2019). The F-test showed significant effects of the two removals in comparison to the control treatment.

Table 1. Total leaf area $\left(\mathrm{m}^{2}\right)$. Total leaf area $\left(\mathrm{m}^{2}\right)$ of $V$. vinifera treated with three different defoliation treatments: four leaf removal (LR4), eight leaf removal (LR8), and no defoliation (CTRL), during two seasons (2018-2019). Measurements were conducted at four times: fruit set (18 June 2018 and 12 June 2019), full veraison (31 July 2018 and 25 July 2019 ), mid-maturation (27 August 2018 and 20 August 2019) and full maturation (25 September 2018 and 18 September 2019). Data (mean $\pm \mathrm{SE}, \mathrm{n}=10$ ) were subjected to one-way ANOVA. Different letters within the same parameter and row indicate significant differences (LSD test, $p \leq 0.05$ ).

\begin{tabular}{ccccccc}
\hline & \multicolumn{3}{c}{ Total Leaf Area (2018) } & \multicolumn{3}{c}{ Total Leaf Area (2019) } \\
\cline { 2 - 6 } Stage & CTRL & LR4 & LR8 & CTRL & LR4 & LR8 \\
\hline Fruit set & $1.15 \pm 0.46 \mathrm{a}$ & $0.77 \pm 0.21 \mathrm{~b}$ & $0.46 \pm 0.12 \mathrm{c}$ & $1.00 \pm 0.38 \mathrm{a}$ & $0.77 \pm 0.17 \mathrm{~b}$ & $0.42 \pm 0.10 \mathrm{c}$ \\
Full veraison & $1.24 \pm 0.40 \mathrm{a}$ & $0.82 \pm 0.12 \mathrm{~b}$ & $0.58 \pm 0.21 \mathrm{~b}$ & $1.11 \pm 0.32 \mathrm{a}$ & $0.86 \pm 0.11 \mathrm{~b}$ & $0.54 \pm 0.17 \mathrm{c}$ \\
Mid-maturation & $1.41 \pm 0.49 \mathrm{a}$ & $0.99 \pm 0.28 \mathrm{~b}$ & $0.87 \pm 0.34 \mathrm{~b}$ & $1.31 \pm 0.26 \mathrm{a}$ & $1.00 \pm 0.31 \mathrm{a}$ & $0.74 \pm 0.23 \mathrm{~b}$ \\
Full maturation & $1.62 \pm 0.34 \mathrm{a}$ & $1.19 \pm 0.43 \mathrm{~b}$ & $0.78 \pm 0.35 \mathrm{c}$ & $1.55 \pm 0.30 \mathrm{a}$ & $1.13 \pm 0.32 \mathrm{ab}$ & $0.82 \pm 0.28 \mathrm{~b}$ \\
\hline
\end{tabular}


No significant differences were noted in chlorophyll a fluorescence $\left(\mathrm{F}_{\mathrm{v}} / \mathrm{F}_{\mathrm{m}}\right)$ and chlorophyll content in leaves of $V$. vinifera as reported in Figure 2A-D.
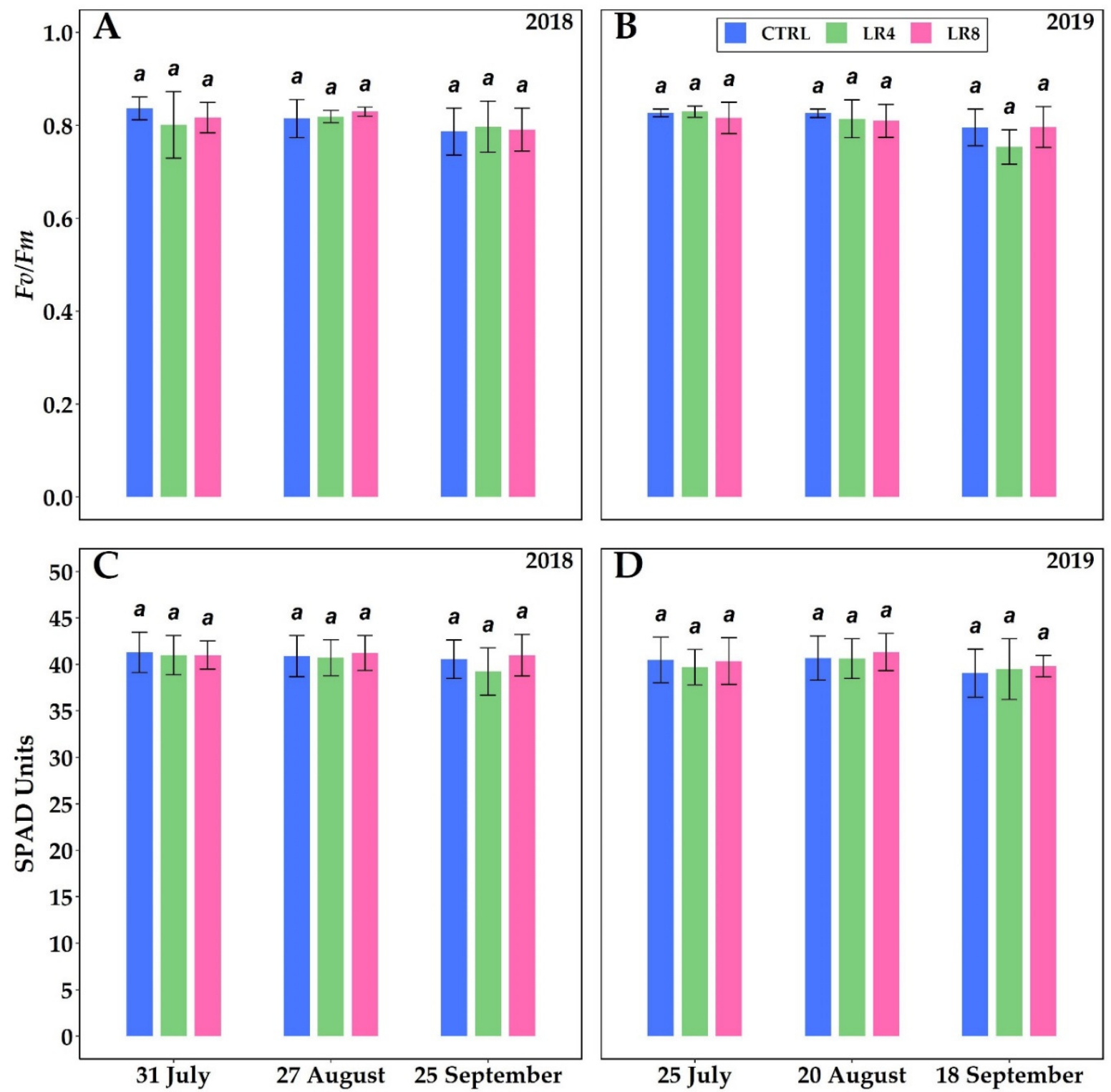

Figure 2. Maximum quantum yield of PSII ( $\left.F_{\mathrm{v}} / \mathrm{F}_{\mathrm{m}}\right)((\mathbf{A}), 2018 ;(\mathbf{B}), 2019)$ and chlorophyll content (SPAD Units) ((C), 2018; (D), 2019) in $V$. vinifera with three different defoliation management methods: four leaf removal (LR4, green column), eight leaf removal (LR8, pink column), and no defoliation (CTRL, blue column). Measurements were conducted at full veraison (31 July 2018 and 25 July 2019), mid-maturation (27 August 2018 and 20 August 2019) and full maturation (25 September 2018 and 18 September 2019). Different letters within the same parameter indicate significant differences. Data (mean $\pm \mathrm{SE}$, $\mathrm{n}=10$ ) were subjected to one-way ANOVA (LSD test, $p \leq 0.05$ ).

The physiological parameters (leaf gas exchanges) of $V$. vinifera in the three different canopy management methods (four leaf removal LR4, eight leaf removal LR8, and no defoliation CTRL) are presented in Table 2.

No significant differences in physiological parameters $\left(\mathrm{P}_{\mathrm{n}}, \mathrm{g}_{\mathrm{s}}\right)$ between LR4 and LR8 during the two study seasons (2018 and 2019) were found; CTRL was significantly different from the other two treatments. No significant differences in leaf water potential among leaf removal treatments were found. Leaf water potential values reflect seasonal trends; peaks of increased water stress were recorded in August, the driest and hottest month. No 
significant differences in $e W U E$ among treatments were found at the mid-maturation stage (27 August 2018 and 20 August 2019).

Table 2. Physiological parameters. Net photosynthesis $\left(P_{n}\right)$, stomatal conductance $\left(g_{s}\right)$, water use efficiency $(e W U E)$ and leaf water potential ( $\Psi_{\text {leaf }}$ ) of $V$. vinifera treated with three different defoliation management methods: four leaf removal (LR4), eight leaf removal (LR8), and no defoliation (CTRL). Measurements were conducted at full veraison, mid-maturation and full maturation. Data (mean $\pm \mathrm{SE}, \mathrm{n}=10$ ) were subjected to one-way ANOVA. Different letters within the same parameter and row indicate significant differences (LSD test, $p \leq 0.05$ ).

\begin{tabular}{|c|c|c|c|c|c|c|}
\hline \multirow[b]{2}{*}{ Stage } & \multicolumn{3}{|c|}{$P_{n}\left(\mu \mathrm{mol} \mathrm{CO} \mathrm{C}^{2} \mathrm{~s}^{-1}\right)$} & \multicolumn{3}{|c|}{$g_{s}\left(\mathrm{mmol} \mathrm{H}_{2} \mathrm{O} \mathrm{m}^{2} \mathrm{~s}^{-1}\right)$} \\
\hline & CTRL & LR4 & LR8 & CTRL & LR4 & LR8 \\
\hline 31 July 2018 & $11.05 \pm 4.11 \mathrm{~b}$ & $14.68 \pm 3.96 \mathrm{a}$ & $15.11 \pm 2.87 \mathrm{a}$ & $126.50 \pm 41.78 \mathrm{~b}$ & $198.00 \pm 31.63 \mathrm{a}$ & $187.70 \pm 24.43 \mathrm{a}$ \\
\hline 27 August 2018 & $8.24 \pm 2.08 b$ & $12.51 \pm 2.62 \mathrm{a}$ & $13.85 \pm 3.85 a$ & $114.87 \pm 16.08 \mathrm{a}$ & $117.70 \pm 26.43 \mathrm{a}$ & $115.35 \pm 32.73 \mathrm{a}$ \\
\hline 25 September 2018 & $7.98 \pm 1.99 b$ & $9.46 \pm 2.76 a$ & $9.16 \pm 3.80 \mathrm{a}$ & $99.49 \pm 22.45 b$ & $120.11 \pm 34.17 \mathrm{a}$ & $124.10 \pm 24.53 \mathrm{a}$ \\
\hline 25 July 2019 & $10.65 \pm 3.42 b$ & $15.42 \pm 1.58 \mathrm{a}$ & $15.55 \pm 1.57 \mathrm{a}$ & $116.25 \pm 35.66 \mathrm{~b}$ & $145.10 \pm 33.85 b$ & $209.80 \pm 29.30 \mathrm{a}$ \\
\hline 20 August 2019 & $7.58 \pm 2.68 b$ & $11.93 \pm 2.56 \mathrm{a}$ & $12.53 \pm 3.37 \mathrm{a}$ & $99.60 \pm 20.41 b$ & $115.55 \pm 32.17 \mathrm{a}$ & $102.88 \pm 29.15 \mathrm{ab}$ \\
\hline \multirow[t]{2}{*}{18 September 2019} & $5.82 \pm 2.33 b$ & $7.61 \pm 2.56 \mathrm{a}$ & $7.64 \pm 3.75 \mathrm{a}$ & $92.30 \pm 22.70 \mathrm{a}$ & $91.40 \pm 31.75 \mathrm{a}$ & $95.65 \pm 33.08 \mathrm{a}$ \\
\hline & \multicolumn{3}{|c|}{ eWUE $\left(\mu \mathrm{mol} \mathrm{CO} \mathrm{CO}_{2} / \mathrm{mmol} \mathrm{H}_{2} \mathrm{O}\right)$} & \multicolumn{3}{|c|}{$\Psi_{\text {leaf }}(\mathrm{MPa})$} \\
\hline Stage & CTRL & LR4 & LR8 & CTRL & LR4 & LR8 \\
\hline 31 July 2018 & $2.64 \pm 0.54 b$ & $2.26 \pm 0.31 \mathrm{ab}$ & $1.58 \pm 0.60 \mathrm{a}$ & $-1.04 \pm 1.41 \mathrm{a}$ & $-1.07 \pm 1.22 \mathrm{a}$ & $-1.03 \pm 1.39 \mathrm{a}$ \\
\hline 27 August 2018 & $2.00 \pm 0.37 \mathrm{a}$ & $1.82 \pm 0.64 \mathrm{a}$ & $1.69 \pm 0.68 \mathrm{a}$ & $-1.27 \pm 1.71 \mathrm{a}$ & $-1.28 \pm 1.81 \mathrm{a}$ & $-1.36 \pm 0.99 a$ \\
\hline 25 September 2018 & $2.89 \pm 0.32 b$ & $2.02 \pm 0.55 \mathrm{a}$ & $2.11 \pm 0.84 \mathrm{a}$ & $-1.25 \pm 1.36 \mathrm{a}$ & $-1.26 \pm 1.52 \mathrm{a}$ & $-1.20 \pm 1.33 \mathrm{a}$ \\
\hline 25 July 2019 & $2.76 \pm 0.78 b$ & $1.70 \pm 0.82 \mathrm{a}$ & $1.68 \pm 0.46 \mathrm{a}$ & $-1.07 \pm 0.70 \mathrm{a}$ & $-1.05 \pm 1.08 \mathrm{a}$ & $-1.06 \pm 0.98 \mathrm{a}$ \\
\hline 20 August 2019 & $1.65 \pm 0.54 \mathrm{a}$ & $1.49 \pm 0.23 \mathrm{a}$ & $1.45 \pm 0.46 \mathrm{a}$ & $-1.28 \pm 1.79 \mathrm{a}$ & $-1.30 \pm 1.95 a$ & $-1.37 \pm 1.13 \mathrm{a}$ \\
\hline 18 September 2019 & $2.53 \pm 0.75 b$ & $1.77 \pm 0.83 \mathrm{ab}$ & $1.41 \pm 0.59 \mathrm{a}$ & $-1.29 \pm 1.77 \mathrm{a}$ & $-1.29 \pm 1.61 \mathrm{a}$ & $-1.21 \pm 1.68 \mathrm{a}$ \\
\hline
\end{tabular}

\subsection{Berry Composition and Temperature}

Tables 3 and 4 show the composition of $V$. vinifera berries under three different canopy management approaches in the two study years in terms of technological and phenolic maturities.

Table 3. Technological maturity. Sugar content ( ${ }^{\circ}$ Brix), titratable acidity (TA), $\mathrm{pH}$ and berry weight of $V$. vinifera treated with three different defoliation managements: four leaf removal (LR4), eight leaf removal (LR8), and no defoliation (CTRL). Measurements were conducted at full veraison (31 July 2018 and 25 July 2019), mid-maturation (27 August 2018 and 20 August 2019) and full maturation (25 September 2018 and 18 September 2019). Data (mean $\pm S E, n=10$ ) were subjected to one-way ANOVA. Different letters within the same parameter and row indicate significant differences (LSD test, $p \leq 0.05)$.

\begin{tabular}{ccccccc}
\hline & \multicolumn{3}{c}{ Sugar Content ( ${ }^{\circ}$ Brix) } & \multicolumn{2}{c}{ TA (mg L ${ }^{-1}$ Tartaric Acid) } \\
\hline Stage & CTRL & LR4 & LR8 & CTRL & LR4 & LR8 \\
\hline 31 July 2018 & $12.92 \pm 0.09 \mathrm{a}$ & $13.81 \pm 0.28 \mathrm{a}$ & $12.7 \pm 0.35 \mathrm{a}$ & $13.84 \pm 0.07 \mathrm{a}$ & $13.68 \pm 0.05 \mathrm{a}$ & $14.52 \pm 0.09 \mathrm{a}$ \\
27 August 2018 & $22.00 \pm 0.12 \mathrm{a}$ & $21.89 \pm 0.18 \mathrm{a}$ & $20.81 \pm 0.20 \mathrm{a}$ & $6.90 \pm 0.10 \mathrm{~b}$ & $7.30 \pm 0.07 \mathrm{ab}$ & $7.74 \pm 0.03 \mathrm{a}$ \\
25 September 2018 & $26.16 \pm 0.09 \mathrm{a}$ & $26.88 \pm 0.15 \mathrm{a}$ & $25.19 \pm 0.05 \mathrm{~b}$ & $5.98 \pm 0.03 \mathrm{ab}$ & $5.86 \pm 0.04 \mathrm{~b}$ & $6.41 \pm 0.06 \mathrm{a}$ \\
\hline 25 July 2019 & $13.10 \pm 0.06 \mathrm{~b}$ & $16.29 \pm 0.10 \mathrm{a}$ & $13.08 \pm 0.07 \mathrm{~b}$ & $13.42 \pm 0.08 \mathrm{a}$ & $13.00 \pm 0.06 \mathrm{a}$ & $13.82 \pm 0.07 \mathrm{a}$ \\
20 August 2019 & $22.50 \pm 0.07 \mathrm{a}$ & $22.59 \pm 0.03 \mathrm{a}$ & $21.26 \pm 0.15 \mathrm{a}$ & $6.36 \pm 0.04 \mathrm{~b}$ & $6.70 \pm 0.08 \mathrm{ab}$ & $7.54 \pm 0.010 \mathrm{a}$ \\
18 September 2019 & $26.90 \pm 0.22 \mathrm{~b}$ & $27.75 \pm 0.21 \mathrm{a}$ & $25.98 \pm 0.19 \mathrm{c}$ & $5.43 \pm 0.07 \mathrm{~b}$ & $5.53 \pm 0.09 \mathrm{~b}$ & $6.02 \pm 0.06 \mathrm{a}$ \\
\hline & & pH & & & Berry Weight (g) & LR4 \\
\hline Stage & CTRL & LR4 & LR8 & CTRL & LR4 \\
\hline 31 July 2018 & $2.60 \pm 0.05 \mathrm{a}$ & $2.75 \pm 0.02 \mathrm{a}$ & $2.55 \pm 0.05 \mathrm{a}$ & $0.88 \pm 0.02 \mathrm{a}$ & $0.81 \pm 0.04 \mathrm{a}$ & $0.82 \pm 0.02 \mathrm{a}$ \\
27 August 2018 & $3.28 \pm 0.08 \mathrm{a}$ & $3.22 \pm 0.04 \mathrm{a}$ & $3.10 \pm 0.05 \mathrm{a}$ & $1.12 \pm 0.10 \mathrm{a}$ & $1.00 \pm 0.08 \mathrm{ab}$ & $0.90 \pm 0.05 \mathrm{~b}$ \\
25 September 2018 & $3.53 \pm 0.03 \mathrm{a}$ & $3.54 \pm 0.02 \mathrm{a}$ & $3.22 \pm 0.04 \mathrm{~b}$ & $1.18 \pm 0.05 \mathrm{a}$ & $1.16 \pm 0.02 \mathrm{a}$ & $1.13 \pm 0.03 \mathrm{a}$ \\
\hline 25 July 2019 & $3.04 \pm 0.08 \mathrm{a}$ & $3.02 \pm 0.03 \mathrm{a}$ & $3.02 \pm 0.07 \mathrm{a}$ & $0.85 \pm 0.04 \mathrm{a}$ & $0.75 \pm 0.03 \mathrm{a}$ & $0.70 \pm 0.04 \mathrm{~b}$ \\
20 August 2019 & $3.30 \pm 0.02 \mathrm{a}$ & $3.28 \pm 0.03 \mathrm{a}$ & $3.21 \pm 0.01 \mathrm{a}$ & $1.03 \pm 0.05 \mathrm{a}$ & $0.92 \pm 0.05 \mathrm{a}$ & $0.98 \pm 0.03 \mathrm{a}$ \\
18 September 2019 & $3.70 \pm 0.05 \mathrm{a}$ & $3.64 \pm 0.03 \mathrm{a}$ & $3.05 \pm 0.02 \mathrm{~b}$ & $1.15 \pm 0.08 \mathrm{a}$ & $1.12 \pm 0.05 \mathrm{a}$ & $1.12 \pm 0.03 \mathrm{a}$ \\
\hline
\end{tabular}


No significant difference in $\mathrm{pH}$ was found at full veraison and mid-maturation in both seasons, while a significant difference in $\mathrm{pH}$ was found at harvest: the LR8 treatment showed the lowest values (3.22 in 2018 and 3.05 in 2019). Consequently, LR8 was given the highest total acidity values during full maturation in both seasons $\left(6.41 \mathrm{mg} \mathrm{L}^{-1}\right.$ and 6.02 $\mathrm{mg} \mathrm{L}^{-1}$, respectively). Regarding sugar content values, significant differences at harvest were noted in both seasons: LR4 and CTRL had the highest values (26.88 and $26.16^{\circ}$ Brix in 2018 and 27.75 and $26.90^{\circ}$ Brix in 2019 , respectively).

Table 4. Phenolic maturity. Total anthocyanin (Tot. Anth.), extractable anthocyanin (Extr. Anth.), total polyphenol (Tot. Polyp.), and extractable polyphenol (Extr. Polyp.) contents of $V$. vinifera treated with three different defoliation managements: four leaf removal (LR4), eight leaf removal (LR8), and no defoliation (CTRL). Measurements were conducted at full veraison (31 July 2018 and 25 July 2019), mid-maturation (27 August 2018 and 20 August 2019) and full maturation (25 September 2018 and 18 September 2019). Data (mean $\pm S E, n=10$ ) were subjected to one-way ANOVA. Different letters within the same parameter and row indicate significant differences (LSD test, $p \leq 0.05$ ).

\begin{tabular}{|c|c|c|c|c|c|c|}
\hline \multirow[b]{2}{*}{ Stage } & \multicolumn{3}{|c|}{ Tot. Anth. (mg L ${ }^{-1}$ ) } & \multicolumn{3}{|c|}{ Extr. Anth. (mg L $\left.{ }^{-1}\right)$} \\
\hline & CTRL & LR4 & LR8 & CTRL & LR4 & LR8 \\
\hline 31 July 2018 & $751.41 \pm 27.68 \mathrm{~b}$ & $880.25 \pm 16.44 \mathrm{a}$ & $738.50 \pm 10.68 b$ & $370.40 \pm 9.21 \mathrm{~b}$ & $393.73 \pm 13.86 \mathrm{a}$ & $344.15 \pm 9.41 c$ \\
\hline 27 August 2018 & $1450.75 \pm 24.87 b$ & $1550.50 \pm 21.22 \mathrm{a}$ & $1312.50 \pm 17.89 c$ & $638.75 \pm 15.87 b$ & $653.75 \pm 11.04 \mathrm{a}$ & $595.00 \pm 14.16 c$ \\
\hline 25 September 18 & $1690.15 \pm 23.55 b$ & $1830.12 \pm 19.48 \mathrm{a}$ & $1490.75 \pm 14.32 \mathrm{c}$ & $737.15 \pm 7.60 \mathrm{~b}$ & $850.15 \pm 10.09 \mathrm{a}$ & $645.25 \pm 13.91 c$ \\
\hline 25 July 2019 & $938.23 \pm 11.74 b$ & $1030.20 \pm 8.86 \mathrm{a}$ & $910.51 \pm 7.53 \mathrm{~b}$ & $561.22 \pm 7.60 \mathrm{~b}$ & $743.20 \pm 15.58 \mathrm{a}$ & $505.34 \pm 14.78 c$ \\
\hline 20 August 2019 & $1605.20 \pm 10.00 \mathrm{~b}$ & $2030.77 \pm 12.62 \mathrm{a}$ & $1459.50 \pm 12.62 \mathrm{c}$ & $1241.27 \pm 9.44 b$ & $1470.50 \pm 7.66 \mathrm{a}$ & $1025.31 \pm 11.73 c$ \\
\hline \multirow[t]{2}{*}{18 September 19} & $1711.00 \pm 23.14 b$ & $2227.50 \pm 7.08 \mathrm{a}$ & $1437.30 \pm 21.98 c$ & $782.51 \pm 16.12 b$ & $1087.78 \pm 9.12 \mathrm{a}$ & $695.37 \pm 10.07 c$ \\
\hline & \multicolumn{3}{|c|}{ Tot. Polyp. (mg L ${ }^{-1}$ ) } & \multicolumn{3}{|c|}{ Extr. Polyp. (mg L $\left.{ }^{-1}\right)$} \\
\hline Stage & CTRL & LR4 & LR8 & CTRL & LR4 & LR8 \\
\hline 31 July 2018 & $3164.54 \pm 46.76 b$ & $3247.10 \pm 43.16 \mathrm{a}$ & $3195.27 \pm 36.89 b$ & $2832.80 \pm 39.67 \mathrm{a}$ & $2889.67 \pm 45.98 \mathrm{a}$ & $2876.90 \pm 42.76 \mathrm{a}$ \\
\hline 27 August 2018 & $3395.87 \pm 31.72 b$ & $3439.08 \pm 33.05 \mathrm{ab}$ & $3457.15 \pm 29.34 \mathrm{a}$ & $2920.60 \pm 45.00 \mathrm{a}$ & $2974.97 \pm 34.16 \mathrm{a}$ & $2901.56 \pm 67.81 \mathrm{a}$ \\
\hline 25 September 18 & $3367.29 \pm 49.15 \mathrm{a}$ & $3155.70 \pm 54.25 \mathrm{~b}$ & $3389.34 \pm 44.21 \mathrm{a}$ & $2889.45 \pm 32.57 \mathrm{a}$ & $2950.12 \pm 54.15 a$ & $2745.98 \pm 64.75 b$ \\
\hline 25 July 2019 & $4021.65 \pm 24.43 \mathrm{a}$ & $4005.21 \pm 37.78 \mathrm{a}$ & $4051.81 \pm 37.60 \mathrm{a}$ & $3682.59 \pm 29.62 \mathrm{a}$ & $3614.36 \pm 55.08 \mathrm{a}$ & $3669.18 \pm 63.12 \mathrm{a}$ \\
\hline 20 August 2019 & $3996.14 \pm 43.22 \mathrm{a}$ & $4013.25 \pm 47.25 \mathrm{a}$ & $3848.61 \pm 34.31 \mathrm{~b}$ & $3600.45 \pm 42.00 \mathrm{a}$ & $3609.67 \pm 24.17 \mathrm{a}$ & $3565.45 \pm 35.90 \mathrm{~b}$ \\
\hline 18 September 19 & $3576.17 \pm 38.27 \mathrm{a}$ & $3520.16 \pm 32.25 a$ & $3598.28 \pm 34.46 a$ & $3369.11 \pm 57.51 b$ & $3481.57 \pm 55.15 a$ & $3306.21 \pm 45.32 b$ \\
\hline
\end{tabular}

The greatest differences were found with regard to the composition of extractable anthocyanins in both seasons. At full veraison, mid- and full maturation, LR4 berries showed significantly higher extractable anthocyanin content compared to LR8 and CTRL berries in 2018 and 2019. The lowest values were recorded for the LR8 treatment at the three different stages: $344.15,595.00$, and $645.25 \mathrm{mg} \mathrm{L}^{-1}$ during the 2018 season and 505.34, 1025.31, and $695.37 \mathrm{mg} \mathrm{L}^{-1}$ during the 2019 season. At full maturation, LR4 berries showed significantly higher extractable polyphenol content compared to the other two treatments. No differences in total polyphenols at harvest were found.

Figure 3 shows berry temperature $\left({ }^{\circ} \mathrm{C}\right)$ of $V$. vinifera among the three different canopy management approaches during the study period for the two years. 

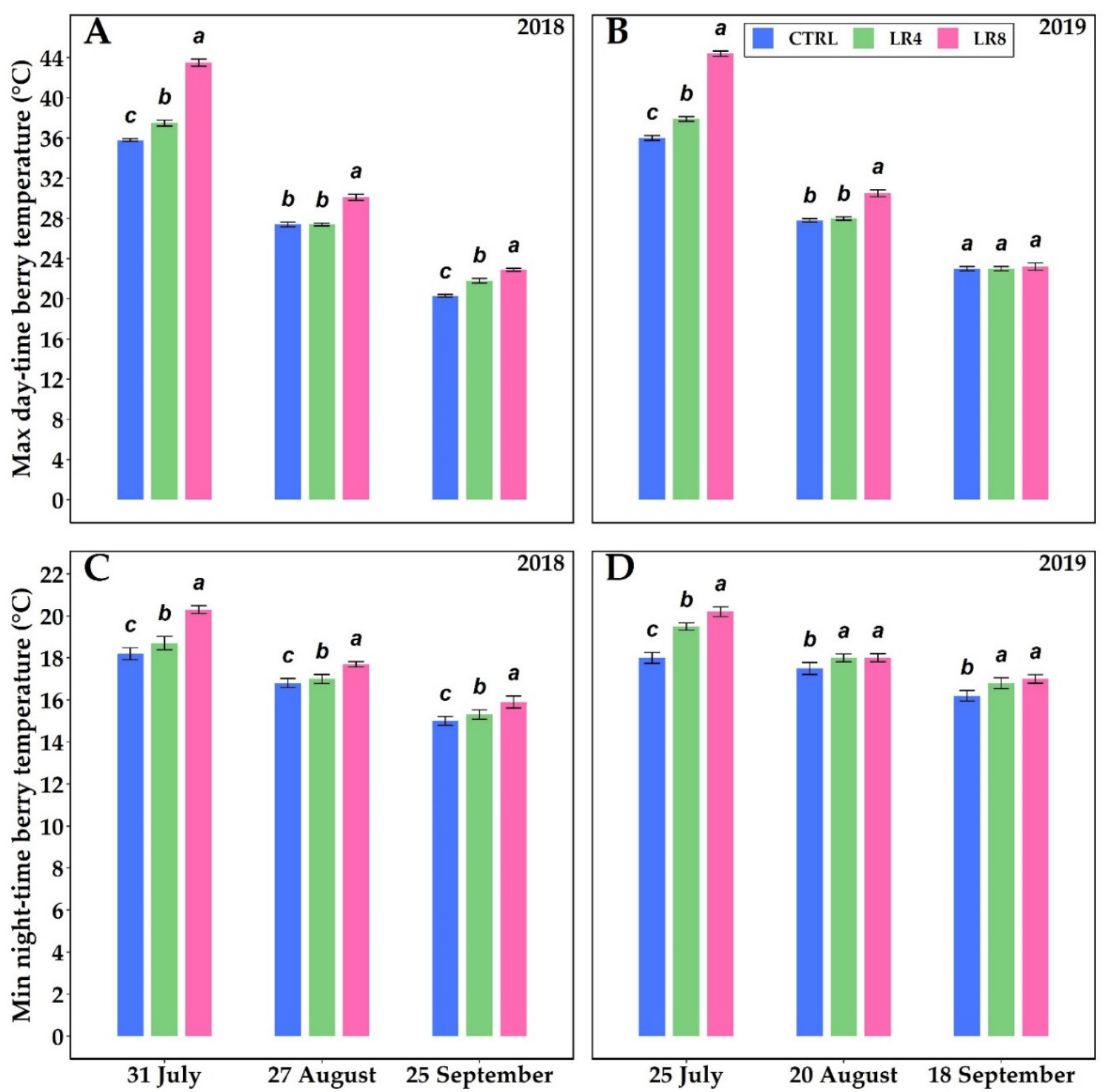

Figure 3. Maximum daytime temperature $\left({ }^{\circ} \mathrm{C}\right)((\mathbf{A}), 2018 ;(\mathbf{B}), 2019)$ and minimum night-time temperature $\left({ }^{\circ} \mathrm{C}\right)((\mathbf{C}), 2018$; (D), 2019) of $V$. vinifera berries with three different defoliation managements: four leaf removal (LR4, green column), eight leaf removal (LR8, pink column), and no defoliation (CTRL, blue column). Measurements were conducted at full veraison (31 July 2018 and 25 July 2019), mid-maturation (27 August 2018 and 20 August 2019) and full maturation (25 September 2018 and 18 September 2019). Different letters within the same parameter indicate significant differences. Data (mean \pm SE, $\mathrm{n}=10$ ) were subjected to one-way ANOVA (LSD test, $p \leq 0.05$ ).

The maximum daytime and minimum night-time temperatures of berries at three different phenological phases were investigated (Figure 3). Temperature decreased from July until September when it dropped steadily. The highest daytime temperature values were recorded in the LR8 treatment, reaching $43.5^{\circ} \mathrm{C}$ and $44.4^{\circ} \mathrm{C}$ on 31 July 2018 and 25 July 2019, respectively. The same trend was observed for night-time temperature. The CTRL treatment gave the lowest values during the 2018 and 2019 seasons.

Figure 4 shows production data of $V$. vinifera among three different canopy management, under two years. No significant differences were found. 

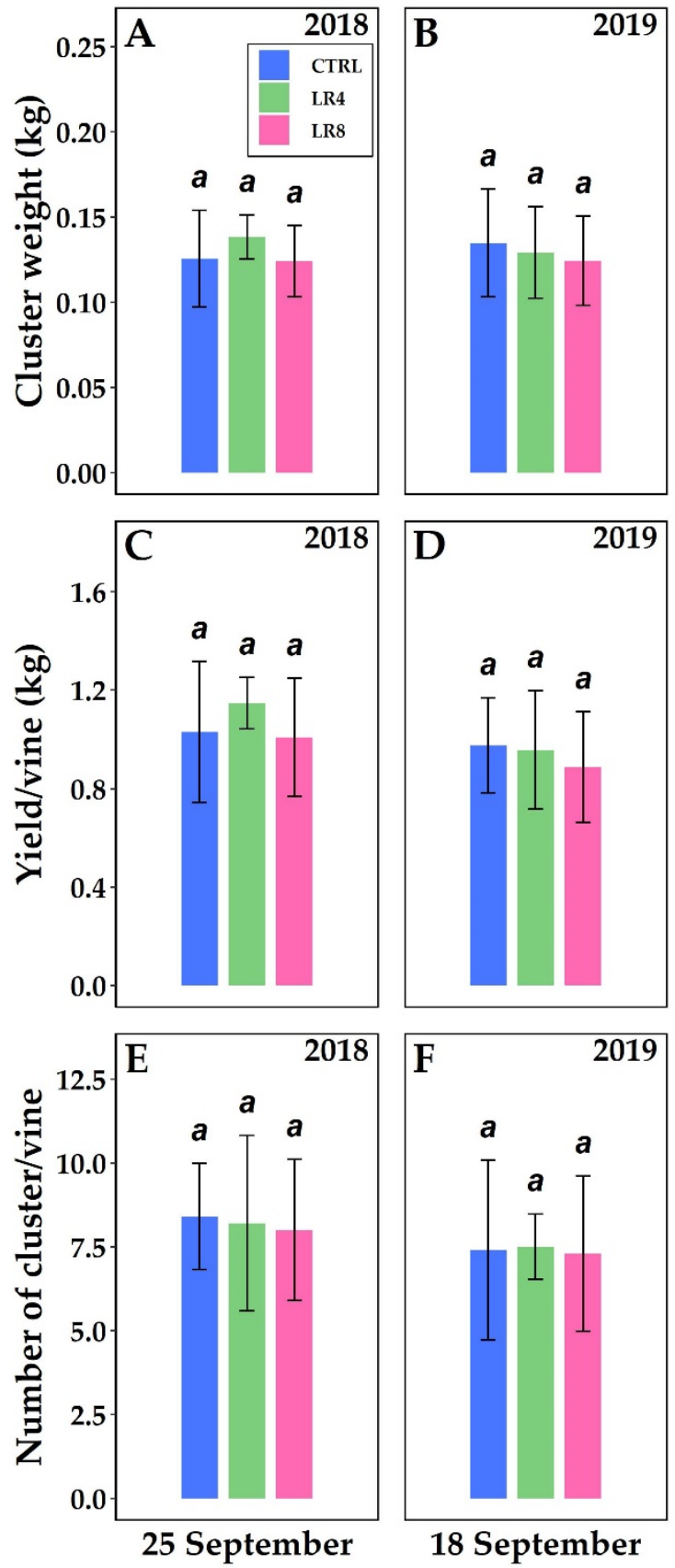

Figure 4. Cluster weight (kg) ((A), 2018; (B), 2019), yield/vine (kg) ((C), 2018; (D), 2019), and number of cluster/vine ((E), 2018; (F), 2019) of V. vinifera with three different defoliation management: four leaf removal (LR4, green column), eight leaf removal (LR8, pink column), and no defoliation (CTRL, blue column). Measurements were conducted at full maturation (25 September 2018 and 18 September 2019). Different letters within the same parameter indicate significant differences. Data (mean $\pm \mathrm{SE}, \mathrm{n}=10$ ) were subjected to one-way ANOVA (LSD test, $p \leq 0.05$ ).

\section{Discussion}

The principal objective of canopy management is to maintain an environment that encourages suitable vegetative growth of vines and safeguards future clusters [45]. Practices include shoot trimming, vigor control, and leaf removal in the fruit zone [46,47].

This study assesses the importance of canopy management in the Mediterranean area through leaf removal as a potential tool to improve Cabernet Sauvignon grape quality.

Defoliation reduced the leaf area of the vines in this study by approximately $25 \%$ in the LR4 and $45 \%$ in the LR8 treatment. Considering a single leaf, net photosynthesis 
$\left(\mathrm{P}_{\mathrm{n}}\right)$ was lower in CTRL at veraison, mid-maturation, and full maturation. Defoliation increases single leaf photosynthesis [48]. However, in a LR8 treatment, leaf removal from the lower quarter of the canopy during berry growth can cause a significant decrease in whole-vine photosynthesis, thus suggesting that higher specific photosynthesis is not able to compensate the reduction in total leaf area $[49,50]$. Therefore, it is probable that leaf thinning reduces the potential $\mathrm{CO}_{2}$ assimilating surface, which potentially decreases total photosynthetic rates and influences the vine's carbon balance [51]. Instead, it has been hypothesized that in the LR4 treatment, there were no changes in whole-vine photosynthesis (a vine maintained its photosynthesis rate even though $27 \%$ of the leaf area had been removed [50]). Generally, the rate of photosynthesis declines as the season progresses [52-55]. Unlike other plant species, a minimally reduced source-sink ratio resulted in no increased stomatal conductance, as well as no higher photosystem II (PSII) efficiency [56].

In both years studied, stomatal conductance, even in the hottest period, maintained optimal values: Cabernet Sauvignon reflects its anisohydric-conservative behavior under stress conditions without showing a drop in values [57]. Although water stress threshold values were found in August (in 2018: $-1.27,-1.28,-1.36 \mathrm{MPa}$ and in 2019: $-1.28,-1.30$, $-1.37 \mathrm{MPa}$ ) [58], no significant differences were recorded in terms of leaf water potential.

Fluorescence of chlorophyll a (an indicator of photo-oxidative stress [59]) leads to us saying in our experiment that in both years, there was neither damage to PSII nor even excessively limiting situations for plants as no significant differences were seen in the two vintages.

In our study, berry temperatures were influenced by defoliation. An increase in sun exposure leads to temperature elevation and fully exposed clusters are subjected to more pronounced fluctuations in daytime and night-time temperatures [60]. In July 2018, the LR4 treatment presented a daytime berry temperature that was $4.75 \%$ higher than CTRL; LR8 was $24.35 \%$ higher. In 2019, LR4 daytime berry temperature was 5.50\% higher than CTRL; LR8 was $23.70 \%$ higher. The timing of fruit set basal defoliation has a stronger impact on the source-sink balance and light and temperature exposure than veraison defoliation [61].

In accordance with Zoecklein et al. [25], drastic leaf removal at harvest (25 September 2018 and 18 September 2019) reduced fruit soluble solids concentration: the sugar content of LR8 was lower than the other two treatments. Depending on the growth environment, values of between 7 and $14 \mathrm{~cm}^{2}$ of leaf area per gram of berry are often quoted as being necessary to satisfactorily ripen the fruit [62]. In fact, a drastic reduction in leaf area due to leaf removal could negatively affect the carbon balance and allocation to sinks as well as reproductive activity which may, in turn, negatively affect plant carbohydrate reserve replenishment $[63,64]$. On the other hand, partial defoliation (LR4) can improve vine performance [65]: the LR4 treatment presented the highest sugar content during the 2019 season.

As pointed out by Main et al. [66], leaf removal treatments had no effect on berry weight.

Leaf removal (LR4 treatment) generally increased fruit titratable acidity (TA), which was associated with a greater malic acid concentration [67].

With regard to the total and extractable anthocyanins and extractable polyphenols at harvest, the LR4 treatment gave the highest values. An increase in grape flavonol and anthocyanin concentration as an outcome of defoliation is due to sunlight-driven upregulation biosynthesis of polyphenols [68]. While the LR8 treatment had the lowest accumulation of both anthocyanins and polyphenols, this was probably due to excess sun exposure and excess temperature. In fact, some studies have reported that high levels of light and temperature have led to a decrease in anthocyanin levels [69]. It was highlighted that the lower anthocyanin content in berries under high temperature reflects the impact of reduced biosynthesis with an increased degradation (peroxidase enzymes in anthocyanin catabolism) [70]. The higher anthocyanin content in our LR4 treatment could also be due to a greater sugar content, which could, in turn, lead to an accumulation of this flavonoid [71]. 


\section{Materials and Methods}

\subsection{Experimental Design and Settings}

The experiment was carried out in a Vitis vinifera L. (cv. Cabernet Sauvignon, clonal selection 685) vineyard situated on a sandy soil in Bolgheri, Castagneto Carducci, Tuscany $\left(43^{\circ} 23^{\prime} 39^{\prime \prime} \mathrm{N} ; 10^{\circ} 61^{\prime} 6^{\prime \prime} \mathrm{E}\right)$ with an elevation of $96 \mathrm{~m}$ a.s.l. with south-west exposure. Soil horizons present a clay texture with the following characteristics: sand $40.1 \%$; silt $32.5 \%$; clay $27.4 \%$; organic matter $1.3 \%$; $\mathrm{pH}\left(\mathrm{H}_{2} \mathrm{O}\right)$ 7.6. The experiment was set up during two consecutive seasons (2018 and 2019). The vineyard was planted in 2009 on 1103 P rootstock at a spacing of 1.1 by $2 \mathrm{~m}(\sim 4545$ vines/ha) and trained on a vertical shoot positioning system in SE-NW oriented rows with a single cordon system, at $70 \mathrm{~cm}$ above ground with six spurs (12 buds per vine). The vines do not have irrigation and cultural practices were the common ones in the area. Pest treatments were applied as per local practices; no sprays against Botrytis were performed (Tuscan integrated management).

The following three management methods were tested: removal of the first four leaves of each primary shoot (LR4), removal of the first eight leaves of each primary shoot (LR8), and no defoliation treatment (CTRL). Treatments were performed at the same time during the season, at fruit set, right after the machine shoot trimming. Treatments were applied according to a randomized block design with 10 replications per treatment. A single span, composed of five plants, was considered as a replication. Leaf removal was carried out on 18 June 2018 and on 12 June 2019. As in Mucalo's experiment [72], in the defoliated nodes, lateral shoots were removed (they experience the highest photosynthetic activity during ripening and can cause a carry-off effect). Maximum, minimum, mean air temperatures $\left({ }^{\circ} \mathrm{C}\right)$ and global radiation $\left(\mathrm{W} \mathrm{m}^{-2}\right)$ of the growing season (2018-2019) were collected daily from a weather station located in the vineyard (Ecotech, Germany); rainfall and air humidity were also recorded. As described thereafter, eco-physiological measurements were performed on 10 vines/management method (10 vines per treatment; one vine per replication) at three different dates corresponding to three different phenological stages: 31 July 2018 and 25 July 2019 (full veraison, 100\% of berries present full color change; E-L 36 stage); 27 August 2018 and 20 August 2019 (mid-maturation; E-L 37 stage); 25 September 2018 and 18 September 2019 (full maturation; E-L 38 stage) [73].

\subsection{Leaf Gas Exchanges, Leaf Area, Leaf Water Potential, Leaf Chlorophyll a Fluorescence and Content}

Leaf gas exchange (transpiration rate $(E)$, net photosynthesis $\left(P_{n}\right)$, and stomatal conductance $\left(g_{s}\right)$ ) was measured using a portable infrared gas analyzer (model Ciras 3, PP Systems, Amesbury, MA, USA), between 10 and 12 a.m. on 10 fully developed and healthy leaves per treatment (10 replicates, one each vine). The photosynthesis/transpiration ratio, extrinsic water use efficiency (eWUE), was calculated. Measurements were performed, setting the leaf chamber flow under the same conditions as the experiment of [74]: saturating photosynthetic photon flux of $1300 \mu \mathrm{mol} \mathrm{m}{ }^{-2} \mathrm{~s}^{-1}$, ambient $\mathrm{CO}_{2}$ concentration $\sim 400 \mathrm{ppm}$, and ambient temperature) at the three phenological stages as mentioned above. Based on the correlation between the vein length on the lower surface and leaf area, the leaf area of total assimilation area per vine was established by a non-destructive method [75]. Total leaf area was calculated by multiple regression analysis based on the following variables: leaf number, shoot length, and area of the smallest and largest leaf; in addition, the total leaf area was established using the number of shoots per plant [76].

Leaf water potential $\left(\Psi_{\text {leaf }}, \mathrm{MPa}\right)$ was determined using a pressure chamber (model 600 , PMS Instrument Co., Albany, OR, USA) on 10 fully expanded leaves per treatment, at approximately 12 noon-1:00 p.m. [77].

Using a chlorophyll fluorometer (Handy-PEA ${ }^{\circledR}$, Hansatech Instruments, Norfolk, UK), the fluorescence of chlorophyll a (Chl-a) was recorded; the leaves were adapted to the dark for $30 \mathrm{~min}$ with the help of leaf clips. $\mathrm{F}_{\mathrm{v}} / \mathrm{F}_{\mathrm{m}}$ (variable/maximal Chl-a fluorescence, the maximum quantum yield of photosystem PSII) was calculated following Maxwell and 
Johnson's methodology [78] and were collected by applying a saturating flash of actinic light at $3000 \mu \mathrm{mol}$ photons $\mathrm{m}^{-2} \mathrm{~s}^{-1}$ for $1 \mathrm{~s}$.

A 502 SPAD device (Konica Minolta Inc., Japan) was used to measure chlorophyll a content in leaves. At the same three stages, Chl-a content, leaf water potential, and Chl-a fluorescence were measured on the same leaves used for leaf gas exchange measurements.

\subsection{Berry Composition and Temperature}

Choosing 20 sample berries per plant, 100 berries per replication were randomly harvested at full veraison, mid-maturation and full maturation from each treatment to perform technological maturity assessments. With a digital scale (model ES2201, Artiglass, Due Carrare, PD, Italy), each sample was individually weighed and the berries were then squeezed to for $\mathrm{pH}$, sugar content, and titratable acidity (TA) analyses. A refractometer (PCE-Oe Inst., Lucca, Italy) was used to evaluate sugar content $\left({ }^{\circ}\right.$ Brix). A portable $\mathrm{pH}$ meter (PCE-Oe Inst., Lucca, Italy) was used to evaluate $\mathrm{pH}$ of grape must, and, using $0.1 \mathrm{M} \mathrm{NaOH}$ to an end-point of $\mathrm{pH} 7.0, \mathrm{~g} \mathrm{~L}^{-1}$ tartaric acid (TA) was calculated by manual glass burette on a $10 \mathrm{~mL}$ sample. To determine the optimum harvesting time, berries from three different experimental plots were tested every other day with a digital hand refractometer and harvesting time was considered optimal when the sugar content in all treatments reached $25^{\circ}$ Brix. In addition, another 100-berry sample/vine/thesis (10 berry samples per plant) was used to determine phenolic contents as well as extractable and total anthocyanins [79]. During the three phenological phases, the daytime and nighttime temperatures (12-1 p.m. and 2-3 a.m., respectively) of the bunch were measured by temperature probes (micro temperature probe-GMR_MTP) inserted inside the berries (GMR Strumenti SAS, Scandicci, Italy) [80,81]. A datalogger was connected to the probes of the single cluster.

\subsection{Statistical Analysis}

Data from each season (2018-2019) were separately analyzed by means of one-way ANOVA with defoliation treatments as the main factor $(p \leq 0.05)$. In addition, mean values were separated by Fisher's least significant difference (LSD) post hoc test $(p \leq 0.05)$. $p$ value adjustment was performed with the Holm method. All statistical analyses were performed using $\mathrm{R}$ and RStudio (Boston, MA, USA) [82].

\section{Conclusions}

The present research investigated the influence of basal leaf removal on vine physiology, berry temperature, and grape quality based on three methods (removal of four leaves, LR4; eight leaves, LR8; and no defoliation, CTRL). Under defoliation conditions, considering the single leaf, vines treated with LR4 and LR8 maintained higher photosynthesis levels compared to CTRL. In terms of berry traits, higher sugar and anthocyanins content were detected in LR4 berries. These effects may make LR4 treatment a candidate as a practical tool for winemakers who want to increase vine performance. Overall, LR8 vines presented a slow maturation with unchanged berry weight and higher titratable acidity in comparison with LR4 and CTRL vines; this method could be useful for rosé wine production. Furthermore, the sharp decrease in anthocyanin concentration under severe defoliation suggests that the influence of light and temperature are dominant in the degradation of these compounds. To fully validate and clarify the effects of leaf removal on secondary metabolites (amount and extraction), further investigations are needed. Investigation of the processes of assimilation of $\mathrm{CO}_{2}$ at the level of the whole vine would also be useful.

Author Contributions: The experiment was designed, conceptualized and organized by G.B.M., E.C., L.S., F.P. and M.F. followed the execution of treatments, made measurements of gas exchanges, water potentials and sampled berries. E.C. and L.S. processed data and carried out statistical analyses. E.C. wrote the original draft manuscript, which was edited and improved by G.B.M. All authors have read and accepted the published version of the manuscript. 
Funding: This research received no external funding.

Institutional Review Board Statement: Not applicable.

Informed Consent Statement: Not applicable.

Data Availability Statement: Not applicable.

Acknowledgments: The authors thank the Viticulture and Oenology Research Centre (CREA) for its help with field sampling.

Conflicts of Interest: The authors declare no conflict of interest.

\section{References}

1. Sabbatini, P.; Howell, G.S. Effects of early defoliation on yield, fruit composition, and harvest season cluster rot complex of grapevines. HortScience 2010, 45, 1804-1808. [CrossRef]

2. Bavaresco, L.; Gatti, M.; Pezzutto, S.; Fregoni, M.; Mattivi, F. Effect of leaf removal on grape yield, berry composition, and stilbene concentration. Am. J. Enol. Vitic. 2008, 59, 292-298.

3. Hunter, J.J.; De Villiers, O.T.; Watts, J.E. The effect of partial defoliation on quality characteristics of Vitis vinifera L. cv. Cabernet Sauvignon grapes. II. Skin color, skin sugar, and wine quality. Am. J. Enol. Vitic. 1991, 42, 13-18.

4. Smart, R.E.; Smith, S.M.; Winchester, R.V. Light quality and quantity effects on fruit ripening for Cabernet Sauvignon. Am. J. Enol. Vitic. 1988, 39, 250-258.

5. Diago, M.P.; Ayestaran, B.; Guadalupe, Z.; Poni, S.; Tardaguila, J. Impact of prebloom and fruit set basal leaf removal on the flavonol and anthocyanin composition of Tempranillo grapes. Am. J. Enol. Vitic. 2012, 63, 367-376. [CrossRef]

6. Diago, M.P.; Ayestaran, B.; Guadalupe, Z.; Garrido, A.; Tardaguila, J. Phenolic composition of Tempranillo wines following early defoliation of the vines. J. Sci. Food Agric. 2012, 92, 925-934. [CrossRef] [PubMed]

7. Intrigliolo, D.S.; Llacer, E.; Revert, J.; Esteve, M.D.; Climent, M.D.; Palau, D.; Gómez, I. Early defoliation reduces cluster compactness and improves grape composition in Mandó, an autochthonous cultivar of Vitis vinifera from southeastern Spain. HortScience 2014, 167, 71-75. [CrossRef]

8. Risco, D.; Pérez, D.; Yeves, A.; Castel, J.R.; Intrigliolo, D.S. Early defoliation in a temperate warm and semi-arid Tempranillo vineyard: Vine performance and grape composition. Aust. J. Grape Wine Res. 2014, 20, 111-122. [CrossRef]

9. Ćirković, D.; Matijašević, S.; Deletić, N.; Ćirković, B.; Gašić, U.; Sredojević, M.; Jovanović, Z.; Djurić, V.; Tešić, Ž. The Effect of Early and Late Defoliation on Phenolic Composition and Antioxidant Properties of Prokupac Variety Grape Berries (Vitis vinifera L.). Agronomy 2019, 9, 822. [CrossRef]

10. Howell, G.S.; Mansfield, T.K.; Wolpert, J.A. Influence of training system, pruning severity, and thinning on yield, vine size, and fruit quality of Vidal blanc grapevines. Am. J. Enol. Vitic. 1987, 38, 105-112.

11. Poni, S.; Casalini, L.; Bernizzoni, F.; Civardi, S.; Intrieri, C. Effects of early defoliation on shoot photosynthesis, yield components, and grape composition. Am. J. Enol. Viticult. 2006, 57, 397-407.

12. Poni, S.; Bernizzoni, F. A three-year study on the impact of pre-flowering leaf removal on berry growth components and grape composition in cv. Barbera vines. J. Int. Sci. Vigne Vin. 2010, 44, 21-30.

13. Cataldo, E.; Salvi, L.; Sbraci, S.; Storchi, P.; Mattii, G.B. Sustainable Viticulture: Effects of Soil Management in Vitis vinifera. Agronomy 2020, 10, 1949. [CrossRef]

14. Kliewer, W.M. Effect of time and severity of defoliation on growth and composition of Thompson Seedless grapes. Am. J. Enol. Vitic. 1970, 21, 37-47.

15. Intrieri, C.; Filippetti, I.; Allegro, G.; Centinari, M.; Poni, S. Early defoliation (hand vs. mechanical) for improved crop control and grape composition in Sangiovese (Vitis vinifera L.). Aust. J. Grape Wine Res. 2008, 14, 25-32. [CrossRef]

16. Poni, S.; Bernizzoni, F.; Briola, G.; Cenni, A. Effects ofearly leaf removal on cluster morphology, shoot efficiency andgrape quality in two Vitis vinifera cultivars. Acta Hortic. 2005, 689, 217-225. [CrossRef]

17. Gatti, M.; Bernizzoni, F.; Civardi, S.; Poni, S. Effects of cluster thinning and preflowering leaf removal on growth and grape composition in cv. Sangiovese. Am. J. Enol. Vitic. 2012, 63, 325-332. [CrossRef]

18. Diago, M.P.; Vilanova, M.; Tardaguila, J. Effects of timing of manual and mechanical early defoliation on the aroma of Vitis vinifera L. Tempranillo wine. Am. J. Enol. Vitic. 2010, 61, 382-391.

19. Lee, J.; Skinkis, P. Oregon Pinot noir grape anthocyanin enhancement by early leaf removal. Food Chem. 2013, 139, 893-901. [CrossRef] [PubMed]

20. Yu, R.; Cook, M.G.; Yacco, R.S.; Watrelot, A.A.; Gambetta, G.; Kennedy, J.A.; Kurtural, S.K. Effects of leaf removal and applied water on flavonoid accumulation in grapevine (Vitis vinifera L. cv. Merlot) berry in a hot climate. J. Agric. Food Chem. 2016, 64, 8118-8127. [CrossRef] [PubMed]

21. May, P.; Shaulis, N.J.; Antcliff, A.J. The effect of controlled defoliation in the Sultana vine. Am. J. Enol. Vitic. 1969, 20, 237-250.

22. Gómez, I.; Revert, J.; Esteve, M.D.; Climent, M.D.; Martínez, A.; Jiménez, J.; Intrigliolo, D.S. Effects of early defoliation in grape yield and quality in "Mando", an autochthon cultivar of south-east Spain. Acta Hortic. 2012, 931, 365-370. [CrossRef] 
23. Kotseridis, Y.; Georgiadou, A.; Tikos, P.; Kallithraka, S.; Koundouras, S. Effects of severity of post-flowering leaf removal on berry growth and composition of three red Vitis vinifera L. cultivars grown under semiarid conditions. J. Agric. Food Chem. 2012, 60, 6000-6010. [CrossRef] [PubMed]

24. Reynolds, A.G.; Wardle, D.A.; Naylor, A.P. Impact of training system, vine spacing, and basal leaf removal on Riesling. Vine performance, berry composition, canopy microclimate, and vineyard labor requirements. Am. J. Enol. Vitic. 1966, 47, 63-76.

25. Zoecklein, B.W.; Wolf, T.K.; Duncan, N.W.; Judge, J.M.; Cook, M.K. Effects of fruit zone leaf removal on yield, fruit composition, and fruit rot incidence of Chardonnay and White Riesling (Vitis vinifera L.) grapes. Am. J. Enol. Vitic. 1992, 43, $139-148$.

26. Verdenal, T.; Zufferey, V.; Dienes-Nagy, A.; Gindro, K.; Belcher, S.; Lorenzini, F.; Rosti, J.; Koestel, C.; Spring, J.L.; Viret, O. Pre-flowering defoliation affects berry structure and enhances wine sensory parameters. OENO ONE 2017, 51. [CrossRef]

27. Verdenal, T.; Zufferey, V.; Dienes-Nagy, A.; Bourdin, G.; Gindro, K.; Viret, O.; Spring, J.L. Timing and intensity of grapevine defoliation: An extensive overview on five cultivars in Switzerland. Am. J. Enol. Vitic. 2019, 70, 427-434. [CrossRef]

28. Percival, D.C.; Sullivan, J.A.; Fisher, K.H. Effect of cluster exposure, berry contact and cultivar on cuticular membrane formation and occurrence of bunch rot (Botrytis cinerea PERS.: FR.) with 3 Vitis vinifera L. cultivars. Vitis 1993, 32, 87-97.

29. Kunz, B.; Cahill, D.; Mohr, P.; Osmond, M.; Vonarx, J. Plant responses to UV radiation and links to pathogen resistance. Int. Rev. Cytol. 2006, 255, 1-40.

30. Coombe, B.G. Fruit set and development in seeded grape varieties as affected by defoliation, topping, girdling, and other treatments. Am. J. Enol. Vitic. 1959, 10, 85-100.

31. Belancic, A.; Agosin, E.; Ibacache, A.; Bordeu, E.; Baumes, R.; Razungles, A.; Bayonove, C. Influence of sun exposure on the aromatic composition of Chilean Muscat grape cultivars Moscatel de Alejandria and Moscatel rosada. Am. J. Enol. Vitic. 1997, 48, $181-186$.

32. Kozina, B.; Karoglan, M.; Herjavec, S.; Jeromel, A.; Orlic, S. Influence of basal leaf removal on the chemical composition of Sauvignon Blanc and Riesling wines. J. Food Agric. Environ. 2008, 6, 28-33.

33. Radeka, S.; Herjavec, S.; Peršurić, Đ.; Lukić, I.; Sladonja, B. Effect of different maceration treatments on free and bound varietal aroma compounds in wine of Vitis vinifera L. cv. Malvazija istarska bijela. Food Technol. Biotechnol. 2008, 46, 86-92.

34. Bubola, M.; Peršuri'c, D.J.; Gani'c, K.K.; Cossetto, M. Influence of timing and intensity of basal leaf removal on aromatic composition of cv. istrian Malvasia wines. In Abstracts Book III International Symposium; Malvasias: Canary Islands, Spain, 2009; pp. 64-65.

35. Perez, J.R.; Kliewer, W.M. Influence of light regime and nitrate fertilization on nitrate reductase activity and concentrations of nitrate and arginine in tissues of three cultivars of grape vines. Am. J. Enol. Vitic. 1982, 33, 86-93.

36. Roubelakis-Angelakis, K.A.; Kliewer, W.M. Effects of exogenous factors on phenylalanine ammonia-lyase activity and accumulation of anthocyanins and total phenolics in grape berries. Am. J. Enol. Vitic. 1986, 37, 275-280.

37. Dokoozlian, N.K.; Kliewer, W.M. Influence of light on grape berry growth and composition varies during fruit development. J. Am. Soc. Hortic 1996, 121, 869-874. [CrossRef]

38. Mori, K.; Gotto-Yamamoto, N.; Kitayama, M.; Hashizume, K. Loss of anthocyanins in red-wine grape under high temperatures. J. Exp. Bot. 2007, 58, 1935-1945. [CrossRef]

39. Stoll, M.; Lafontaine, M.; Schultz, H.R. Possibilities to reduce the velocity of berry maturation through various leaf area to fruit ratio modifications in Vitis vinifera L. Riesling. Progrès Agric. Vitic. 2010, 127, 68-71.

40. Parker, A.K.; Hofmann, R.W.; Van Leeuwen, C.; McLachlan, A.R.G.; Trought, M.C.T. Manipulating the leaf area to fruit mass ratio alters the synchrony of total soluble solids accumulation and titratable acidity of grape berries. Aust. J. Grape Wine Res. 2015, 21, 266-276. [CrossRef]

41. Parker, A.K.; Raw, V.; Martin, D.; Haycock, S.; Sherman, E.; Trought, M.C.T. Reduced grapevine canopy size post-flowering via mechanical trimming alters ripening and yield of 'Pinot noir'. Vitis 2016, 55, 1-9.

42. Poni, S.; Gatti, M.; Bernizzoni, F.; Civardi, S.; Bobeica, N.; Magnanini, E.; Palliotti, A. Late leaf removal aimed at delaying ripening in cv. Sangiovese: Physiological assessment and vine performance. Aust. J. Grape Wine Res. 2013, 19, 378-387. [CrossRef]

43. Filippetti, I.; Movahed, N.; Allegro, G.; Valentini, G.; Pastore, C.; Colucci, E.; Intrieri, C. Effect of post-veraison source limitation on the accumulation of sugar, anthocyanins and seed tannins in Vitis vinifera cv. Sangiovese berries. Aust. J. Grape Wine Res. 2014, 21, 1-10.

44. Tardaguila, J.; Petrie, P.R.; Poni, S.; Diago, M.P.; Martinez de Toda, F. Effects of mechanical thinning on yield and fruit composition of Tempranillo and Grenache grapes trained to a vertical shoot-positioned canopy. Am. J. Enol. Vitic. 2008, 59, $412-417$.

45. Palliotti, A.; Tombesi, S.; Silvestroni, O.; Lanari, V.; Gatti, M.; Poni, S. Changes in vineyard establishment and canopy management urged by earlier climate-related grape ripening: A review. Sci. Hortic. 2014, 178, 43-54. [CrossRef]

46. Smart, R.E.; Dick, J.K.; Gravett, I.M.; Fisher, B.M. Canopy management to improve grape yield and wine quality-principles and practices. S. Afr. J. Enol. Vitic. 1990, 11, 3-17. [CrossRef]

47. Vasconcelos, M.C.; Castagnoli, S. Leaf canopy structure and vine performance. Am. J. Enol. Vitic. 2000, 51, 390-396.

48. Hunter, J.J.; Visser, J.H. The effect of partial defoliation, leaf position and developmental stage of the vine on the photosynthetic activity of Vitis vinifera L. cv Cabernet Sauvignon. S. Afr. J. Enol. Vitic. 1988, 9, 9-15. [CrossRef]

49. Petrie, P.R.; Trought, M.C.T.; Howell, G.S. Influence of leaf ageing, leaf area and crop load on photosynthesis, stomatal conductance and senescence of grapevine (Vitis vinifera L. cv. Pinot Noir) leaves. Vitis 2000, 39, 31-36. 
50. Petrie, P.R.; Trought, M.C.; Howell, G.S.; Buchan, G.D. The effect of leaf removal and canopy height on whole-vine gas exchange and fruit development of Vitis vinifera L. Sauvignon Blanc. Funct. Plant Biol. 2003, 30, 711-717. [CrossRef]

51. Soar, C.J.; Dry, P.R.; Loveys, B.R. Scion photosynthesis and leaf gas exchange in Vitis vinifera L. cv. Shiraz: Mediation of rootstock effects via xylem sap ABA. Aust. J. Grape Wine Res. 2006, 12, 82-96. [CrossRef]

52. Flexas, J.; Barón, M.; Bota, J.; Ducruet, J.M.; Gallé, A.; Galmés, J.; Jiménez, M.; Pou, A.; Ribas-Carbó, M.; Sajnani, C.; et al. Photosynthesis limitations during water stress acclimation and recovery in the drought-adapted Vitis hybrid Richter-110 ( $V$. berlandieri $\times$ V. rupestris). J. Exp. Bot. 2009, 60, 2361-2377. [CrossRef] [PubMed]

53. Chaves, M.M.; Zarrouk, O.; Francisco, R.; Costa, J.M.; Santos, T.; Regalado, A.P.; Rodrigues, M.L.; Lopes, C.M. Grapevine under deficit irrigation: Hints from physiological and molecular data. Ann. Bot. 2010, 105, 661-676. [CrossRef] [PubMed]

54. Giorio, P.; Nuzzo, V. Leaf area, light environment, and gas exchange in Montepulciano grapevines trained to Tendone trellising system. Plant Biosyst. Int. J. Deal. Asp. Plant Biol. 2012, 146, 322-333.

55. Candolfi-Vasconcelos, M.C.; Koblet, W. Influences of partial defoliation on gas exchange parameters and chlorophyll content of field-grown grapevines: Mechanisms and limitations of the compensation capacity. Vitis 1991, 30, 129-141.

56. Glanz-Idan, N.; Wolf, S. Upregulation of photosynthesis in mineral nutrition-deficient tomato plants by reduced source-to-sink ratio. Plant Signal. Behav. 2020, 15, 1712543. [CrossRef]

57. Sade, N.; Gebremedhin, A.; Moshelion, M. Risk-taking plants: Anisohydric behavior as a stress-resistance trait. Plant. Signal. Behav. 2012, 7, 767-770. [CrossRef]

58. Matese, A.; Baraldi, R.; Berton, A.; Cesaraccio, C.; Di Gennaro, S.F.; Duce, P.; Facini, O.; Mameli, M.G.; Piga, A.; Zaldei, A. Estimation of water stress in grapevines using proximal and remote sensing methods. Remote Sens. 2018, 10, 114. [CrossRef]

59. Mitra, S.; Irshad, M.; Debnath, B.; Lu, X.; Li, M.; Dash, C.K.; Qiu, D. Effect of vineyard soil variability on chlorophyll fluorescence, yield and quality of table grape as influenced by soil moisture, grown under double cropping system in protected condition. PeerJ 2018, 6, e5592. [CrossRef]

60. Bergqvist, J.; Dokoozlian, N.; Ebisuda, N. Sunlight exposure and temperature effects on berry growth and composition of Cabernet Sauvignon and Grenache in the Central San Joaquin Valley of California. Am. J. Enol. Vitic. 2001, 52, 1-7.

61. Pastore, C.; Zenoni, S.; Fasoli, M.; Pezzotti, M.; Tornielli, G.B.; Filippetti, I. Selective defoliation affects plant growth, fruit transcriptional ripening program and flavonoid metabolism in grapevine. BMC Plant Biol. 2013, 13, 1-16. [CrossRef]

62. Jackson, D.I.; Lombard, P.B. Environmental and management practices affecting grape composition and wine quality: A review. Am. J. Enol. Vitic. 1993, 44, 409-430.

63. Holzapfel, B.P.; Smith, J.P.; Field, S.K.; Hardie, W.J. Dynamics of carbohydrate reserves in cultivated grapevines and vine growth. Hortic. Rev. 2010, 37, 143-211.

64. Frioni, T.; Acimovic, D.; Tombesi, S.; Sivilotti, P.; Palliotti, A.; Poni, S.; Sabbatini, P. Changes in within-shoot carbon partitioning in Pinot Noir grapevines subjected to early basal leaf removal. Front. Plant Sci. 2018, 9, 1-11. [CrossRef] [PubMed]

65. Hunter, J.J.; Ruffner, H.P.; Volschenk, C.G.; Le Roux, D.J. Partial defoliation of Vitis vinifera L. cv. Cabernet Sauvignon/99Richter: Effect on root growth, canopy efficiency, grape compo-sition, and wine quality. Am. J. Enol. Vitic. 1995, 46, 306-314.

66. Main, G.L.; Morris, J.R. Leaf-removal effects on Cynthiana yield, juice composition, and wine composition. Am. J. Enol. Vitic. 2004, 55, 147-152.

67. Tardaguila, J.; de Toda, F.M.; Poni, S.; Diago, M.P. Impact of early leaf removal on yield and fruit and wine composition of Vitis vinifera L. Graciano and Carignan. Am. J. Enol. Vitic. 2010, 61, 372-381.

68. Carbonell-Bejerano, P.; Diago, M.-P.; Martínez-Abaigar, J.; Martínez-Zapater, J.M.; Tardáguila, J.; Núñez-Olivera, E. Solar ultraviolet radiation is necessary to enhance grapevine fruit ripening transcriptional and phenolic responses. BMC Plant Biol. 2014, 14, 183. [CrossRef]

69. Spayd, S.E.; Tarara, J.M.; Mee, D.L.; Ferguson, J.C. Separation of sunlight and temperature effects on the composition of Vitis vinifera cv. Merlot berries. Am. J. Enol. Vitic. 2002, 53, 171-182.

70. Movahed, N.; Pastore, C.; Cellini, A.; Allegro, G.; Valentini, G.; Zenoni, S.; Cavallini, E.; D'Incà, E.; Tornielli, G.B.; Filippetti, I. The grapevine VviPrx31 peroxidase as a candidate gene involved in anthocyanin degradation in ripening berries under high temperature. J. Plant Res. 2016, 129, 513-526. [CrossRef]

71. Arrizabalaga, M.; Morales, F.; Oyarzun, M.; Delrot, S.; Gomès, E.; Irigoyen, J.J.; Hilbert, G.; Pascual, I. Tempranillo clones differ in the response of berry sugar and anthocyanin accumulation to elevated temperature. Plant Sci. 2018, 267, 74-83. [CrossRef]

72. Mucalo, A.; Budić-Leto, I.; Lukšić, K.; Maletić, E.; Zdunić, G. Early Defoliation Techniques Enhance Yield Components, Grape and Wine Composition of cv. Trnjak (Vitis vinifera L.) in Dalmatian Hinterland Wine Region. Plants 2021, 10, 551. [CrossRef] [PubMed]

73. Eichhorn, K.W.; Lorenz, D.H. Phänologische Entwick-lungs-stadien der Rebe. Nachrichtenblatt des Deutschen Pflanzen- schutzdienstes, Braunschweig 1977, 29, 119-120.

74. Cataldo, E.; Salvi, L.; Mattii, G.B. Effects of irrigation on ecophysiology, sugar content and thiol precursors (3-S-cysteinylhexan-1-ol and 3-S-glutathionylhexan-1-ol) on Vitis vinifera cv. Sauvignon Blanc. Plant Physiol. Biochem. 2021, 164, 247-259. [CrossRef]

75. Lopes, M.A.; Pinto, P. Easy and accurate estimation of grapevine leaf area with simple mathematical models. Vitis 2005, 44, 55-61.

76. De Miguel, P.S.; Junquera, P.; De la Fuente, M.; Jimenez, L.; Linares, R.; Trujillo, P.B.; Gutiérrez, J.R.L.G. Estimation of vineyard leaf area by linear regression. Span. J. Agric. Res. 2011, 202-212. [CrossRef]

77. Scholander, P.F.; Hammel, H.T.; Bradstreet, E.D.; Hemmingsen, E.A. Sap pressure in vascular plants. Science 1965, 148, 339-346. [CrossRef] [PubMed] 
78. Maxwell, K.; Johnson, G.N. Chlorophyll fluorescence: A practical guide. J. Exp. Bot. 2000, 51, 659-668. [CrossRef]

79. Sommer, S.; Cohen, S.D. Comparison of different extraction methods to predict anthocyanin concentration and color characteristics of red wines. Fermentation 2018, 4, 39. [CrossRef]

80. Yamane, T.; Jeong, S.T.; Goto-Yamamoto, N.; Koshita, Y.; Kobayashi, S. Effects of temperature on anthocyanin biosynthesis in grape berry skins. Am. J. Enol. Vitic. 2006, 57, 54-59.

81. Fernandes de Oliveira, A.; Mercenaro, L.; Del Caro, A.; Pretti, L.; Nieddu, G. Distinctive Anthocyanin Accumulation Responses to Temperature and Natural UV Radiation of Two Field-Grown Vitis vinifera L. Cultivars. Molecules 2015, 20, 2061-2080. [CrossRef]

82. Allaire, J. RStudio: Integrated Development Environment for R; Citeseer: Boston, MA, USA, 2012; Volume 770, p. 394. 